\title{
Repurposing tromethamine as inhaled therapy to treat CF airway disease
}

\author{
Mahmoud H. Abou Alaiwa, ${ }^{1}$ Janice L. Launspach, ${ }^{1}$ Kelsey A. Sheets, ${ }^{1}$ Jade A. Rivera, ${ }^{1}$ \\ Nicholas D. Gansemer, ${ }^{1}$ Peter J. Taft, ${ }^{1}$ Peter S. Thorne, ${ }^{2}$ Michael J. Welsh, ${ }^{1,3,4,5}$ David A. Stoltz, ${ }^{1,3,5,6}$ \\ and Joseph Zabner ${ }^{1,5}$ \\ 'Department of Internal Medicine, Roy J. and Lucille A. Carver College of Medicine, ${ }^{2}$ Department of Occupational and \\ Environmental Health, College of Public Health, ${ }^{3}$ Department of Molecular Physiology and Biophysics, ${ }^{4}$ Howard Hughes \\ Medical Institute, ${ }^{5}$ Pappajohn Biomedical Institute, and ${ }^{6}$ Department of Biomedical Engineering, University of lowa, \\ lowa City, lowa, USA.
}

In cystic fibrosis (CF), loss of CF transmembrane conductance regulator (CFTR) anion channel activity causes airway surface liquid (ASL) pH to become acidic, which impairs airway host defenses. One potential therapeutic approach is to correct the acidic pH in CF airways by aerosolizing $\mathrm{HCO}_{3}{ }^{-}$and/or nonbicarbonate $\mathrm{pH}$ buffers. Here, we show that raising ASL pH with inhaled $\mathrm{HCO}_{3}{ }^{-}$increased $\mathrm{pH}$. However, the effect was transient, and $\mathrm{pH}$ returned to baseline values within $\mathbf{3 0}$ minutes. Tromethamine (Tham) is a buffer with a long serum half-life used as an i.v. formulation to treat metabolic acidosis. We found that Tham aerosols increased ASL pH in vivo for at least 2 hours and enhanced bacterial killing. Inhaled hypertonic saline ( $7 \% \mathrm{NaCl})$ is delivered to people with CF in an attempt to promote mucus clearance. Because an increased ionic strength inhibits ASL antimicrobial factors, we added Tham to hypertonic saline and applied it to CF sputum. We found that Tham alone and in combination with hypertonic saline increased $\mathrm{pH}$ and enhanced bacterial killing. These findings suggest that aerosolizing the $\mathrm{HCO}_{3}{ }^{-}$-independent buffer Tham, either alone or in combination with hypertonic saline, might be of therapeutic benefit in CF airway disease.

Conflict of interest: The University of lowa Research Foundation has submitted patent applications for CF pigs and has licensed materials and technologies to Exemplar Genetics. M.J. Welsh holds equity in Intrexon Corp., which owns Exemplar Genetics.

Submitted: March 11, 2016 Accepted: April 28, 2016 Published: June 2, 2016

Reference information: JCI Insight. 2016;1(8):e87535. doi:10.1172/jci.insight.87535.

\section{Introduction}

Airways evolved with a thin layer of fluid, the airway surface liquid (ASL), that is rich in host defense mechanisms and strategically situated at the interface with the environment (1-9). Appropriate ASL volume, $\mathrm{pH}$, and ionic composition are critical for optimal airway host defense (7, 10-19). In cystic fibrosis (CF), dysfunction of an anion channel, CF transmembrane conductance regulator (CFTR), inhibits 2 important airway host defenses: antimicrobial factors and mucociliary transport (20, 21). Loss of CFTR-mediated $\mathrm{HCO}_{3}^{-}$secretion acidifies ASL $\mathrm{pH}$ and inhibits antimicrobial factors. Loss of $\mathrm{Cl}^{-}$and $\mathrm{HCO}_{3}^{-}$secretion also alters the viscoelastic properties of mucus and reduces mucociliary transport. With these and potentially other host defense impairments, the airways fail to eradicate and dispose of invading microorganisms. As a result, recurrent airway infections and inflammation cause a progressive decline in lung function. Despite advances in antibiotic therapy and mucus clearing maneuvers, airway disease continues to shorten the lives of people with $\mathrm{CF}(22,23)$.

In newborn CF piglets, acidic ASL $\mathrm{pH}$ inhibits antimicrobial factors. Instillation of $\mathrm{HCO}_{3}^{-}$onto the airway surface of CF piglet trachea raised ASL pH and enhanced bacterial killing (20). Conversely, acidifying the ASL of non-CF piglets by increasing $\mathrm{CO}_{2}$ tension inhibited bacterial killing. Small changes in ASL $\mathrm{pH}$ resulted in a large defect in bacterial killing due to the inhibitory effect of acidic $\mathrm{pH}$ on both individual antimicrobial factors and on their synergistic interactions (24).

Another important arm of the airway host defense is mucociliary transport. Mucociliary transport was impaired in vivo in CF piglets. In freshly excised trachea, impaired mucus detachment from CF submucosal glands disrupted mucociliary transport, although it remains uncertain whether defective $\mathrm{HCO}_{3}{ }^{-}$secretion, liquid secretion, or a combination are responsible. Additional studies revealed that an acidic $\mathrm{pH}$ increased ASL viscosity (25).

One potential therapeutic approach to raise ASL $\mathrm{pH}$ is to aerosolize $\mathrm{pH}$ buffers. Indeed, a clinical trial of aerosolized $\mathrm{HCO}_{3}^{-}$in people with $\mathrm{CF}$ is ongoing (ClinicalTrials.gov). Tromethamine (Tham or 
A

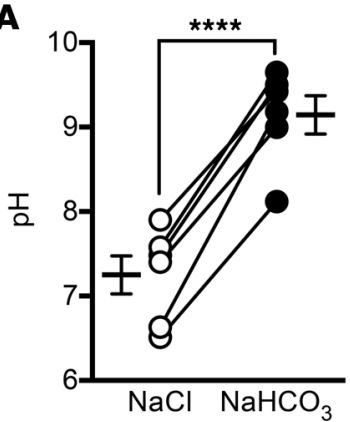

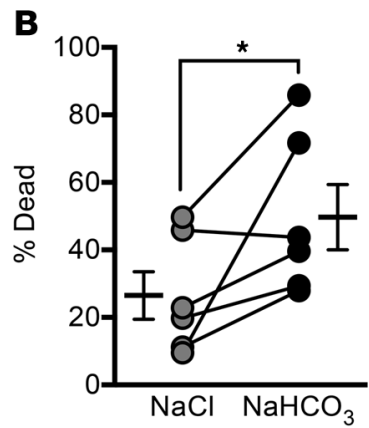

Figure 1. Cystic fibrosis (CF) sputum antimicrobial activity in the presence of $\mathrm{NaHCO}_{3^{*}}$ (A) CF sputum pH and (B) CF sputum antimicrobial activity, in the presence of $200 \mathrm{mM} \mathrm{NaCl}$ or $200 \mathrm{mM} \mathrm{NaHCO}_{3}(1: 1 \mathrm{v} / \mathrm{v})$ at $5 \% \mathrm{CO}_{2}$. Data are mean $\pm \mathrm{SEM}$; some error bars are hidden by symbols. Each data point indicates sputum from a different donor $n=6$. ${ }^{*} P<0.05,{ }^{* * *} P<0.001$ from a Wilcoxon signed-rank test.

tris[hydroxymethyl]aminomethane acetate) is an FDA-approved buffer in clinical use, used to reverse metabolic acidosis (26-28). In contrast to the short-term effect of i.v. $\mathrm{NaHCO}_{3}$, Tham alkalinizes serum with an effect that persists for 16-48 hours (28). Tham is also used as an excipient for inhaled preparations of prostacyclin (29) and nasal preparations of ketorolac (30). Because Tham has a long half-life and prolonged buffering capacity in serum, we hypothesized that inhaled Tham would increase ASL $\mathrm{pH}$ for a longer duration than $\mathrm{HCO}_{3}^{-}$and would enhance ASL bacterial killing. We tested this hypothesis in both pigs and humans with $\mathrm{CF}$.

\section{Results}

$\mathrm{NaHCO}_{3}$ increases the $\mathrm{pH}$ of $\mathrm{CF}$ sputum and enhances its antibacterial activity. To investigate the effect of increasing $\mathrm{CF}$ sputum $\mathrm{pH}$ on bacterial killing, we collected sputa from individuals with $\mathrm{CF}$. We mixed each sputum sample with an equal volume of either $\mathrm{NaHCO}_{3}$ or $\mathrm{NaCl}$. We measured $\mathrm{pH}$ in a humidified chamber at fixed $5 \% \mathrm{CO}_{2}$ using a planar opto-electrode. We also measured bacterial killing. Compared with an equimolar concentration of $\mathrm{NaCl}, \mathrm{NaHCO}_{3}$ increased sputum $\mathrm{pH}$ (Figure $1 \mathrm{~A}$ ). We interrogated the bacterial killing properties of CF sputum by examining the viability of Staphylococcus aureus ( $S$. aureus), one of the first bacteria to infect CF lungs $(23,31,32)$. We attached $S$. aureus to small gold grids and probed the antibacterial properties of the sputum-buffer mixture (20). We recovered the grids 15 minutes later and examined $S$. aureus viability. $\mathrm{NaHCO}_{3}$ increased the $\mathrm{CF}$ sputum ability to kill $S$. aureus in comparison with an equimolar concentration of $\mathrm{NaCl}$ (Figure 1B). These data indicate that adding $\mathrm{NaHCO}_{3}$ raises $\mathrm{CF}$ sputum $\mathrm{pH}$ and enhances its ability to rapidly kill bacteria.

$\mathrm{NaHCO}_{3}$ transiently increases nasal $\mathrm{pH}$. Nebulized $\mathrm{NaHCO}_{3}$ is used safely in patients suffering from acute chlorine gas inhalational injury (33-35). In that clinical setting, the goal is an immediate neutralizing effect from $\mathrm{NaHCO}_{3}$. However, in $\mathrm{CF}$ airways, a longer effect may be required. To test the effect of $\mathrm{NaHCO}_{3}$, we aerosolized $250 \mu \mathrm{l}$ of $200 \mathrm{mM} \mathrm{NaHCO}$ onto the surgically exposed trachea of non-CF piglets and measured ASL pH. $\mathrm{NaHCO}_{3}$ alkalinized ASL pH, but the effect was short-lived and returned to baseline within 30 minutes (Figure 2A). In addition, we aerosolized $250 \mu 1$ of $2 \%(238 \mathrm{mM}) \mathrm{NaHCO}_{3}$ into the nose of healthy human volunteer subjects. Similar to our findings on the porcine tracheal surface, $\mathrm{NaHCO}_{3}$ increased ASL $\mathrm{pH}$, but $\mathrm{pH}$ returned to baseline within 60 minutes (Figure 2, B and C). Increasing the concentration of $\mathrm{NaHCO}_{3}$ to $5 \%$ or $7 \%$ had no additional effect on the duration of the rise in nasal $\mathrm{pH}$ (Figure 2, D-G). Thus, these data suggest that the effect of $\mathrm{NaHCO}_{3}$ on $\mathrm{ASL} \mathrm{pH}$ is transient. Possible explanations include transepithelial $\mathrm{HCO}_{3}^{-}$absorption and/or a rapid shift of $\mathrm{HCO}_{3}^{-}$to $\mathrm{CO}_{2}$ and $\mathrm{H}_{2} \mathrm{O}$.

$\mathrm{HCO}_{3}^{-}$is not required for a $\mathrm{pH}$-related increase in ASL antimicrobial activity. The transient effect of $\mathrm{HCO}_{3}^{-}$on ASL $\mathrm{pH}$ prompted us to find buffers with a longer duration. ASL antimicrobial activity is $\mathrm{pH}$ regulated, yet it remains uncertain whether $\mathrm{HCO}_{3}^{-}$regulates antimicrobial activity independently of its effect on $\mathrm{pH}$. If $\mathrm{HCO}_{3}^{-}$is not required, then any buffer that increases ASL pH may have a therapeutic potential in $\mathrm{CF}$ airways. To investigate whether or not, at a constant $\mathrm{pH}, \mathrm{HCO}_{3}^{-}$enhances cationic peptide activity, we tested the antimicrobial properties of human $\beta$-Defensin-3 (hBD-3; an antimicrobial peptide that is inhibited by ionic strength and $\mathrm{Ca}^{2+}$ ) (36) and LL-37 (an antimicrobial peptide that is not inhibited by ionic strength or $\mathrm{Ca}^{2+}$ ) (37) at different concentrations of $\mathrm{HCO}_{3}^{-}$and a constant $\mathrm{pH}$ of 7.5. We found that increasing $\mathrm{HCO}_{3}{ }^{-}$ concentration in the absence of $\mathrm{Ca}^{2+}$ did not increase hBD-3 and LL-37 activity; in fact, it slightly inhibited their activity (Figure 3, $\mathrm{A}$ and $\mathrm{B}$ ). In the presence of $\mathrm{Ca}^{2+}$, we found that increasing $\mathrm{HCO}_{3}^{-}$inhibited both hBD-3 and LL-37 antimicrobial activity (Figure 3, C and D). These data suggest that, under a constant 

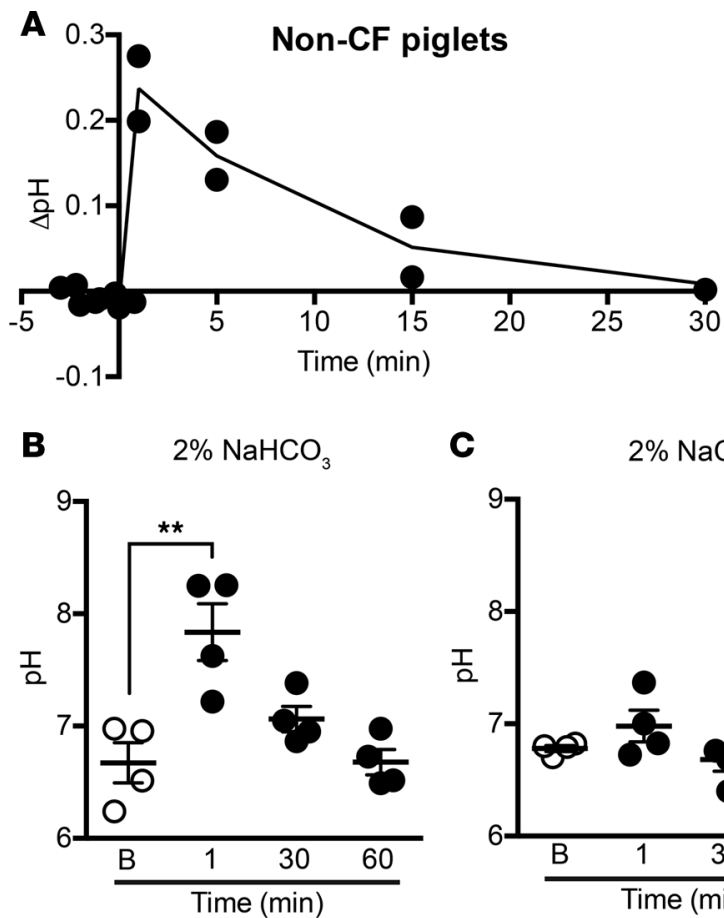

C
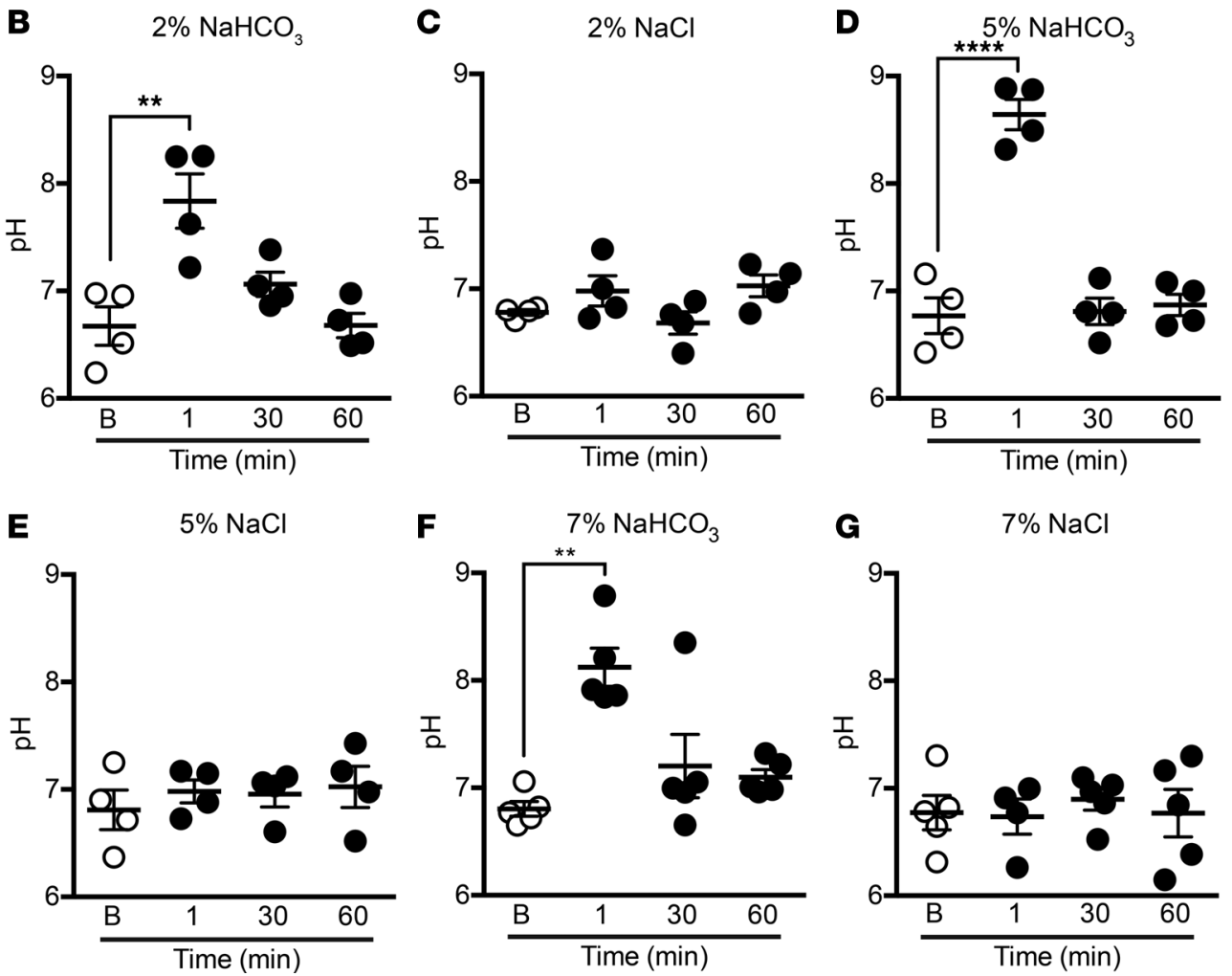

Figure 2. Effect of $\mathrm{NaHCO}_{3}$ on airway surface liquid (ASL) pH. (A) Data represent change in tracheal $A S L \mathrm{pH}$ of WT newborn piglets after instillation of $250 \mu \mathrm{l} 200 \mathrm{mM} \mathrm{NaHCO}_{3}$. Each data point indicates measurements from a different animal, $n=2$. (B-G) Data represent human nasal $\mathrm{pH}$ at baseline and after instillation of $250 \mu \mathrm{l}$ (B) $2 \% \mathrm{NaHCO}_{3}$, (C) $2 \% \mathrm{NaCl}$, (D) $5 \%$ $\mathrm{NaHCO}_{3}$ (E) $5 \% \mathrm{NaCl},(\mathbf{F}) 7 \% \mathrm{NaHCO}_{3}$ and (C) $7 \% \mathrm{NaCl}$. Data are mean \pm SEM; some error bars are hidden by symbols. $n=4-5,1$-way ANOVA, ${ }^{* *} P<0.01$, ***P $<0.001$.

alkaline $\mathrm{pH}$, increasing $\mathrm{HCO}_{3}^{-}$concentrations does not enhance hBD-3 and LL-37 antimicrobial activity. On the contrary, it inhibits it to a small degree. These data, together with our prior finding that increasing pH enhances ASL antimicrobials $(20,24)$, suggest that any buffer that can increase $\mathrm{pH}$ might be used therapeutically to alkalinize ASL in CF.

Tham buffers in the ASL physiological pH range. One possible candidate is Tham (tris[hydroxymethyl] aminomethane), an amine compound with $\mathrm{pKa}$ of 8.07 at $25^{\circ} \mathrm{C}$. Tham has a long half-life when given via i.v. and controls $\mathrm{pH}$ in the physiological range (27). We measured the buffering capacity of $0.3 \mathrm{M}$ Tham and $0.3 \mathrm{M} \mathrm{NaHCO}_{3}$ (equilibrated with $5 \% \mathrm{CO}_{2}$ ). We titrated both buffers with $0.1 \mathrm{M} \mathrm{HCl}$ and calculated the buffering capacity $(\beta)$, the acid equivalents needed to change the $\mathrm{pH}$ of a buffer by $1 \mathrm{pH}$ unit. By plotting the acid titration curve of both $\mathrm{NaHCO}_{3}$ and Tham (Supplemental Figure 1, A and B; supplemental material available online with this article; doi:10.1172/jci.insight.87535DS1) and the first derivative (Supplemental Figure 1, $\mathrm{C}$ and $\mathrm{D}$ ) against $\mathrm{pH}$, we found that $\mathrm{NaHCO}_{3}$ had a significant buffering capacity at a pH range from 6-7 (Supplemental Figure 1C), whereas Tham had a buffering capacity at a slightly broader $\mathrm{pH}$ range from 6.5-8.5 (Supplemental Figure 1D). Moreover, Tham has an additional buffering range at lower $\mathrm{pH}$ values ( $\mathrm{pH}$ 3-6). These data suggest that Tham has an optimal buffering capacity that is within the $\mathrm{pH}$ range of both $\mathrm{CF}$ and non-CF ASL and a wider range than $\mathrm{HCO}_{3}^{-} / \mathrm{CO}_{2}(38-40)$.

Tham enhances $h B D-3$ and LL-37 antimicrobial activity. An alkaline $\mathrm{pH}$ increases the activity of individual ASL antimicrobial peptides and their synergistic interactions (24). Therefore, we tested the effect of Tham on hBD-3 and LL-37 antimicrobial activity. We used a bioluminescence-based assay in which 
A $\quad \mathrm{hBD}-3(1 \mu \mathrm{g} / \mathrm{ml}), \mathrm{pH} 7.5$

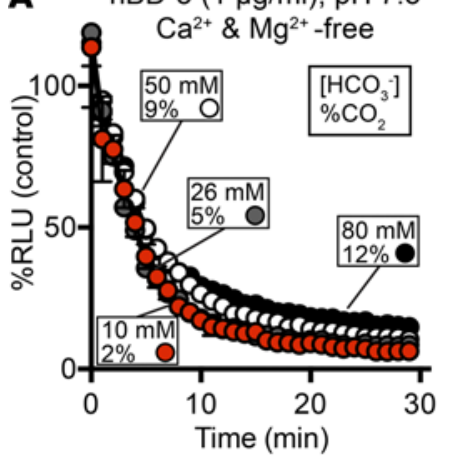

C $\quad \operatorname{hBD}-3(5 \mu \mathrm{g} / \mathrm{ml}), \mathrm{pH} 7.5$

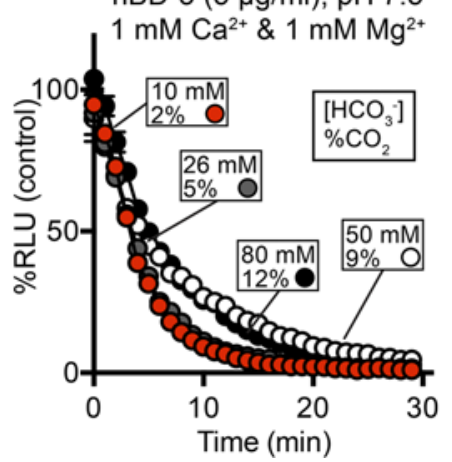

B $\quad$ LL-3 $(100 \mu \mathrm{g} / \mathrm{ml}), \mathrm{pH} 7.5$

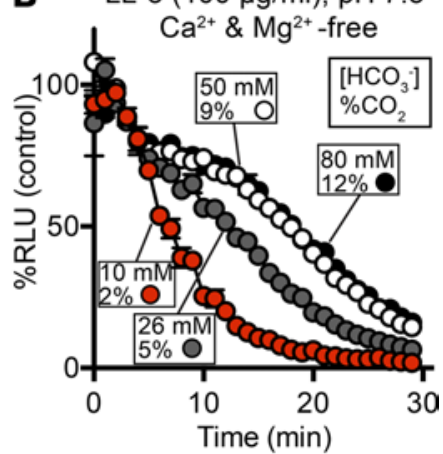

D $\quad \operatorname{LL}-3(100 \mu \mathrm{g} / \mathrm{ml}), \mathrm{pH} 7.5$

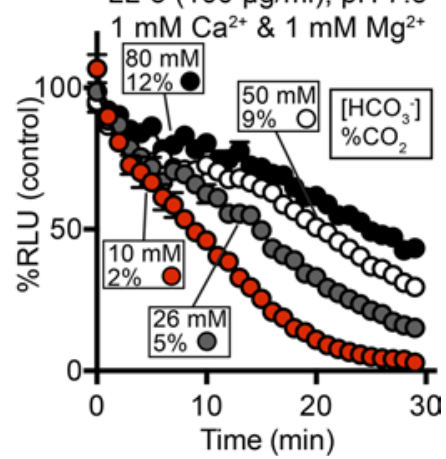

Figure 3. Antimicrobial activity of cathelicidin (LL-37) or human $\beta$-Defensin-3 (hBD-3) in the presence of varying concentrations of NaHCO3. Data represent relative luminescence (RLU) of S. aureus (Xen-29) as a percentage of control (no added antimicrobial and same buffer conditions) at isohydric $\mathrm{pH}$ (same pH of 7.5), and varying concentrations of $\mathrm{NaHCO}_{3} / \% \mathrm{CO}_{2}$ (red circles, $\mathrm{NaHCO}_{3} 10 \mathrm{mM} /$ $\mathrm{CO}_{2} 2 \%$; gray circles, $\mathrm{NaHCO}_{3} 26 \mathrm{mM} / \mathrm{CO}_{2} 5 \%$; open circles, $\mathrm{NaHCO}_{3}$ $50 \mathrm{mM} / \mathrm{CO}_{2} 9 \%$; closed circles, $\left.\mathrm{NaHCO}_{3} 80 \mathrm{mM} / \mathrm{CO}_{2} 12 \%\right)$ in the presence ( $\mathbf{C}$ and $\mathbf{D}$ ) and in the absence ( $\mathbf{A}$ and $\mathbf{B}$ ) of $\mathrm{Ca}^{2+}$ and $\mathbf{M g}^{2+}$. Graphs depict (A) $1 \mu \mathrm{g} / \mathrm{ml} \mathrm{hBD}-3$ and (B) $100 \mu \mathrm{g} / \mathrm{ml} \mathrm{LL}-37$ in the absence of $\mathrm{Ca}^{2+}$ and $\mathrm{Mg}^{2}$. Graphs depict (C) $5 \mu \mathrm{g} / \mathrm{ml} \mathrm{hBD}-3$ and (D) $100 \mu \mathrm{g} / \mathrm{ml}$ $\mathrm{LL}-37$ in the presence of $1 \mathrm{mM} \mathrm{Ca}^{2+}$ and $1 \mathrm{mM} \mathrm{Mg}^{2+}$. Data are mean \pm SEM; some error bars are hidden by symbols. Results are from a single experiment in triplicate. Each experiment was repeated at least 3 times with similar results.

S. aureus Xen-29 was modified to express luminescence genes (41). Compared with an iso-osmolar nonionic control $(\mathrm{pH}=7.02)$, Tham $(\mathrm{pH}=8.65)$ enhanced antimicrobial activity of both hBD-3 (Figure 4A) and LL-37 (Figure 4B). These data suggest that increasing $\mathrm{pH}$ independently of $\mathrm{HCO}_{3}^{-}$concentration enhances hBD-3 and LL-37 antimicrobial activity.

Tham increases the $p H$ of tracheal ASL in CF piglets and enhances bacterial killing. To investigate whether Tham produces a prolonged increase in tracheal ASL pH, we aerosolized Tham onto the airways of non-CF piglets. Tham raised $\mathrm{pH}$ immediately after administration (Figure 5A). While the

effect of $\mathrm{HCO}_{3}^{-}$on ASL returned to baseline by 30 minutes (Figure 2A), the effect of Tham was still higher than baseline at 60 minutes (Figure $5 \mathrm{~A}$ ). We also tested whether aerosolized Tham rescues the bacterial killing defect in CF piglets. We exposed the mucosal surface of airways in newborn CF piglets via a small tracheal widow and aerosolized Tham. We measured ASL pH and bacterial killing 15 minutes after administration of Tham or $\mathrm{NaCl}$ as a control. Tham increased $\mathrm{pH}$ (Figure 5B) and enhanced bacterial killing compared with $\mathrm{NaCl}$ (Figure 5C). The increase in bacterial killing was more pronounced compared with what we found in CF sputum, perhaps because the antimicrobial factors in CF sputum may have been inactivated by proteases, thereby limiting the killing capacity of sputum when compared with ASL $(42,43)$. Thus, these data suggest that Tham increases ASL pH in a sustained manner and it corrects the bacterial killing defect seen in CF pigs.

Tham increases human nasal $\mathrm{pH}$, and the effect is prolonged. To examine whether Tham could also provide a long-tasting buffering effect in human airways, we tested the effect of acute Tham administration on nasal $\mathrm{pH}$. Aerosolized Tham alkalinized the nasal $\mathrm{pH}$ of healthy human subjects, with the effect lasting at least 2 hours (Figure 6A). Administration of an iso-osmolar solution of xylitol, a nonionic sugar, had no effect on nasal $\mathrm{pH}$ (Figure 6B). These findings are similar to the effect of Tham on tracheal ASL $\mathrm{pH}$ in pigs. We also investigated the effect of Tham on nasal $\mathrm{pH}$ in individuals with $\mathrm{CF}$ during one of their clinic visits. In the clinic setting, we were limited to $\mathrm{pH}$ measurements obtained 30 minutes after drug administration. Aerosolization of $250 \mu \mathrm{T}$ Tham increased nasal $\mathrm{pH}$ for 30 minutes, the total duration of the experiment (Figure 6C). Disruption of epithelial integrity in the nasal epithelia could lead to serum leakage and increase $\mathrm{pH}$ to serum levels. The high transepithelial nasal voltage $(\mathrm{Vt})$ seen in $\mathrm{CF}$ patients requires an intact epithelia $(44,45)$. We found that Tham had no effect on nasal Vt (Figure $6 \mathrm{D})$. Thus, Tham appears to produce no disruption of the epithelial barrier integrity, and increases in $\mathrm{pH}$ are likely secondary to a direct buffering effect on ASL.

Tham in combination with hypertonic saline (7\% NaCl) increases $C F$ sputum $p H$ and enhances bacterial killing. Hypertonic saline is often used in individuals with advanced CF airway disease to accelerate mucociliary transport $(46,47)$. However, we and others reported that salt inhibits individual antimicrobial peptides and their synergistic interactions (48-52). Because Tham may be useful as a primary or adjunct inhalational therapy, we asked whether Tham would increase $\mathrm{pH}$ in the presence of hypertonic saline and whether a 

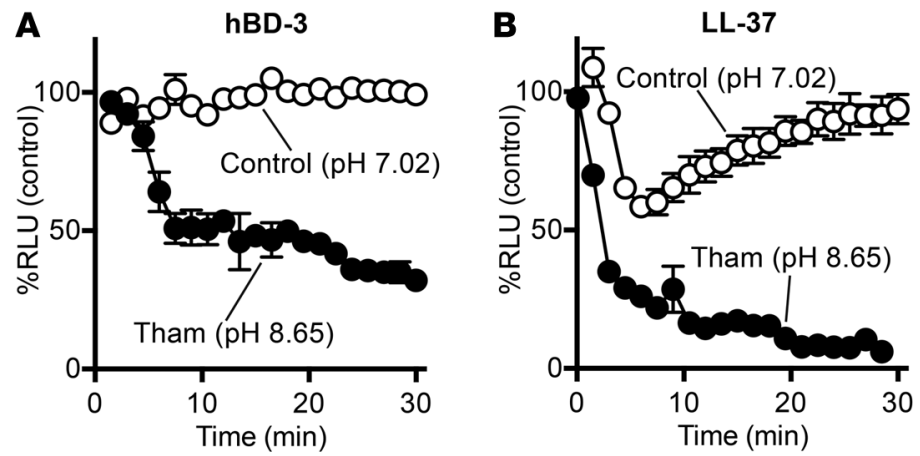

Figure 4. Effect of tromethamine (Tham) on cathelicidin (LL-37) or human $\beta$-Defensin-3 (hBD-3) antimicrobial activity. Data represent relative luminescence (RLU) of S. aureus (Xen-29) as a percentage of control (no added antimicrobial and same buffer conditions) at an ionic strength of $125 \mathrm{mM}$ (1\% Tryptic Soy Broth, $100 \mathrm{mM} \mathrm{NaCl}$ ) in the presence of $10 \mathrm{mM}$ xylitol (nonionic control, open circles, $\mathrm{pH}$ 7.02) or 10 $\mathrm{mM}$ tromethamine (closed circles, $\mathrm{pH} 8.65$ ) and (A) $1 \mu \mathrm{g} / \mathrm{ml} \mathrm{hBD}-3$ or (B) $10 \mu \mathrm{g} / \mathrm{ml} \mathrm{LL-37.} \mathrm{Data} \mathrm{are} \mathrm{mean} \pm \mathrm{SEM}$; some error bars are hidden by symbols. Results are from a single experiment in triplicate. Each experiment was repeated at least 3 times with similar results.

mixture of Tham and hypertonic saline would enhance bacterial killing. We collected sputa from CF subjects and mixed it in a 1:1 (w/v) dilution of Tham $(300 \mathrm{mM})$, hypertonic saline $(1,197 \mathrm{mM}, 7 \% \mathrm{NaCl})$, or a combination of Tham (300 mM) and hypertonic saline (1,197 mM, 7\% NaCl). Compared with hypertonic saline or isotonic saline (in Figure 1), Tham alone or in combination with hypertonic saline raised the $\mathrm{pH}$ of CF sputum (Figure 7A). Similar to the effect of $\mathrm{HCO}_{3}{ }^{-}$on $\mathrm{CF}$ sputum (Figure 1), Tham alone or in combination with hypertonic saline, increased the ability of $\mathrm{CF}$ sputum to kill $S$. aureus compared with hypertonic saline alone (Figure 7B). Although there was a tendency for lower bacterial killing with Tham and hypertonic saline in combination, in comparison with Tham alone, the difference was not statistically significant. Thus, Tham alone or in combination with hypertonic saline is effective at increasing ASL $\mathrm{pH}$ and reversing the bacterial killing defect in CF sputum.

\section{Discussion}

Loss of the CFTR anion channel reduces ASL $\mathrm{pH}$. Our results suggest that both $\mathrm{HCO}_{3}^{-}$and Tham increase ASL $\mathrm{pH}$ in pigs and humans with CF. However, Tham increased ASL $\mathrm{pH}$ for a longer duration than $\mathrm{HCO}_{3}^{-}$. Tham also enhanced ASL bacterial killing in pig airways and human CF sputum. Thus, increasing ASL $\mathrm{pH}$ with Tham might enhance host defense and thereby benefit people with CF.

The surface of the airways lies in proximity with the environment and is constantly exposed to microorganisms. The liquid covering the airways contains a plethora of cationic antimicrobial factors that form the first line of defense against invading bacteria. In previous work, we showed that an abnormally acidic ASL inhibits the activity of individual antimicrobial factors and their combined synergistic interaction (24). Yet, whether the contribution of $\mathrm{pH}$-mediated antimicrobial factor inhibition is $\mathrm{HCO}_{3}^{-}$dependent has been uncertain. Here, we show that, both in the presence and absence of $\mathrm{Ca}^{2+}, \mathrm{HCO}_{3}^{-}$did not increase cationic peptide bacterial killing when $\mathrm{pH}$ was constant. On the contrary, there was a small inhibition. This result suggested that $\mathrm{pH}$ buffers other than $\mathrm{HCO}_{3}^{-}$, such as Tham, might increase ASL antimicrobial activity.

In this study, we identified an FDA-approved i.v. buffer that might be repurposed as

Figure 5. Effect of tromethamine (Tham) on tracheal airway surface liquid (ASL) pH of newborn piglets and ASL bacterial killing. (A) Data represent change in tracheal ASL pH of WT newborn piglets after instillation of $250 \mu \mathrm{l} 0.3 \mathrm{M}$ tromethamine. Data are mean $\pm \mathrm{SEM}, n=3$, Wilcoxon signed-rank test, ${ }^{*} P<0.05$. (B) ASL pH in exposed tracheal window of CF untreated piglets (gray circles) and 15 minutes after tromethamine treatment (closed circles). Data are mean $\pm \mathrm{SEM}$; some error bars are hidden by symbols. $n=6$, Wilcoxon signed-rank test, ${ }^{*} P<0.05$. (C) ASL bacterial killing in exposed tracheal window of CF untreated piglets (gray circles, $n=4$ ) and 15 minutes after tromethamine treatment (closed circles, $n=4-5$ ). Data are mean \pm SEM, Wilcoxon-Mann-Whitney test, ${ }^{* *} P<0.01$.

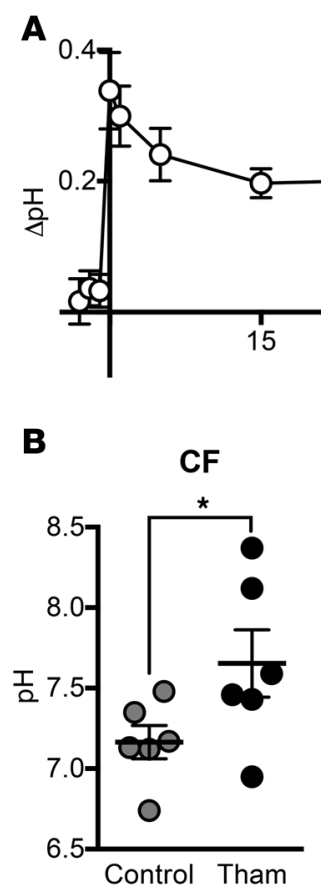

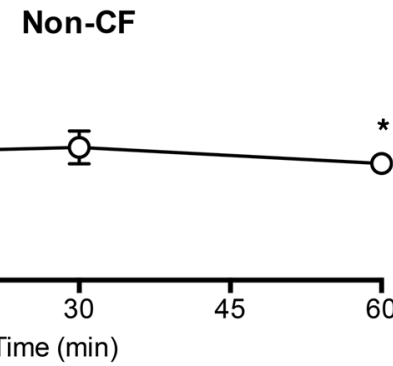

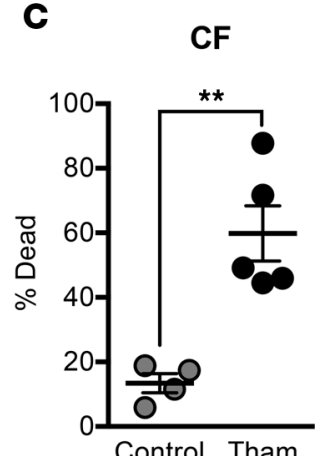


A

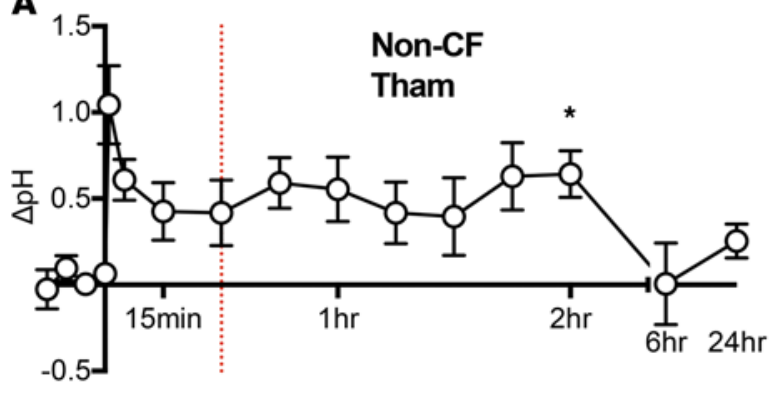

B

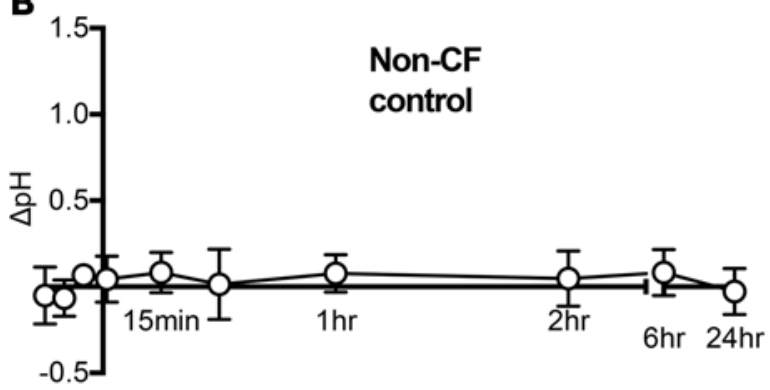

C

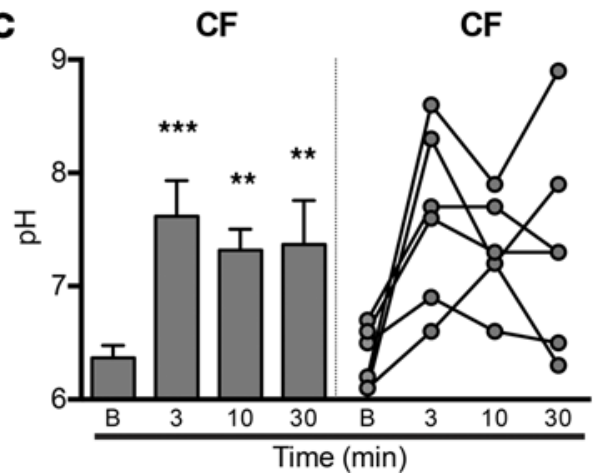

D

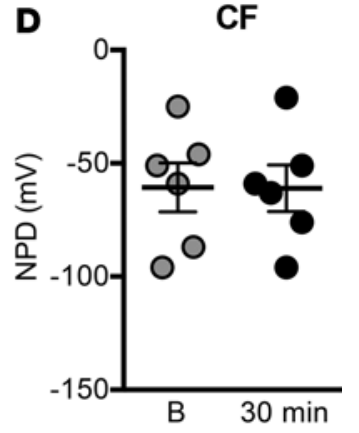

Figure 6. Effect of tromethamine (Tham) on nasal pH measurements. Data represent nasal $\mathrm{pH}$ of healthy volunteers after instillation of $250 \mu \mathrm{l}$ (A) $0.3 \mathrm{M}$ tromethamine (red dashed line represent the duration of the effect of $\mathrm{HCO}_{3}^{-}$) or (B) $0.3 \mathrm{M}$ xylitol (nonionic control). Data are mean \pm SEM; some error bars are hidden by symbols, $n=$ 5 , Wilcoxon signed-rank test, ${ }^{*} P<0.05$. (C) Nasal pH of subjects with cystic fibrosis (CF) at baseline and after instillation of $250 \mu \mathrm{l}$ tromethamine. Bar graph on the left represents the mean $\mathrm{pH} \pm \mathrm{SEM}$ The graph on the right shows $\mathrm{pH}$ data from individual subjects over time. Data are mean $\pm \mathrm{SEM}$; some error bars are hidden by symbols, $n=6$, 1-way ANOVA with Holm-Sidak's Multiple Comparison Test, ${ }^{* *} P<0.01,{ }^{* *} P<0.005$. (D) Transepithelial voltage (Vt) in $\mathrm{mV}$ of CF subjects at baseline (B, gray circles) and 30 minutes (closed circles) after exposure to $250 \mu \mathrm{l} 0.3 \mathrm{M}$ tromethamine. $n=6$, Wilcoxon signed-rank test.

an aerosol to alkalinize the ASL of CF airways (53). Tham is a biologically inert weak amine base with an elimination half-life of 16-48 hours after i.v. administration (28). In addition to i.v. usage, Tham is included as an expedient in many topical, injectable, and/or inhalational FDA-approved drugs. Both iloprost inhalation solution (Ventavis) and nasal Ketorolac Tham (SPRIX) are formulated with Tham with a safe toxicological profile. Similar to its effect on $\mathrm{pH}$ in the serum, in the airways, Tham may alkalinize the ASL by buffering protons. In the serum of patients with acidosis, Tham is protonated. Because protonated Tham is cell impermeable, cellular absorption is reduced, and as a result, the effect on serum $\mathrm{pH}$ is sustained (28). A similar mechanism may be responsible for the prolonged effect in the airways.

Loss of CFTR reduces airway epithelial $\mathrm{HCO}_{3}^{-}$secretion, diminishes ASL $\mathrm{pH}$, and interferes with at least 2 important host defenses: antibacterial activity and mucociliary transport. Each defect may independently contribute to lung disease in CF (10). Treating people with CF with antibiotics improves their clinical status, without correcting the mucus abnormalities. Accordingly, inhaled Tham might be beneficial, even it only corrects the antimicrobial defect. While increasing ASL $\mathrm{pH}$ will change the viscoelastic properties of CF mucus, it is unclear whether such changes in $\mathrm{pH}$ and viscosity would enhance MCT.

This study has several advantages: (i) we studied 2 species, humans and pigs; (ii) we examined the effect of Tham on host defense both in vivo and in vitro; (iii) we tested pristine uninfected airways, as well as sputum from people with advanced CF airway disease; and (iv) we assayed ASL pH and a host defense defect associated with CF airway disease.

This study has also limitations. The experiments were not designed to measure the half-life of Tham in ASL. Moreover, we studied an important pathogen in early CF airway disease, S. aureus. However, P. aeruginosa is the predominant pathogen in advanced CF airway disease. Therefore, it remains to be determined whether inhaled Tham will also restore killing of $P$. aeruginosa. Lastly, our studies examined a transient effect of Tham and raised the question of whether intermittent correction of the ASL pH is sufficient to reverse the bacterial killing host defense defect in CF airways. Should therapy be targeted toward early (infant) or late (adult) CF airway disease? Additional longitudinal studies in pigs and humans will be designed to answer these questions.

Hypertonic saline increases mucociliary transport and decreases the frequency of CF exacerbations (46, 5458). We and others have previously shown that salt inhibits ASL cationic peptides $(52,59)$. Our data show that Tham increases sputum $\mathrm{pH}$ and improves bacterial killing even in the presence of hypertonic saline. We speculate that perhaps a combination of Tham and hypertonic saline might be of therapeutic benefit in CF airways. 
A

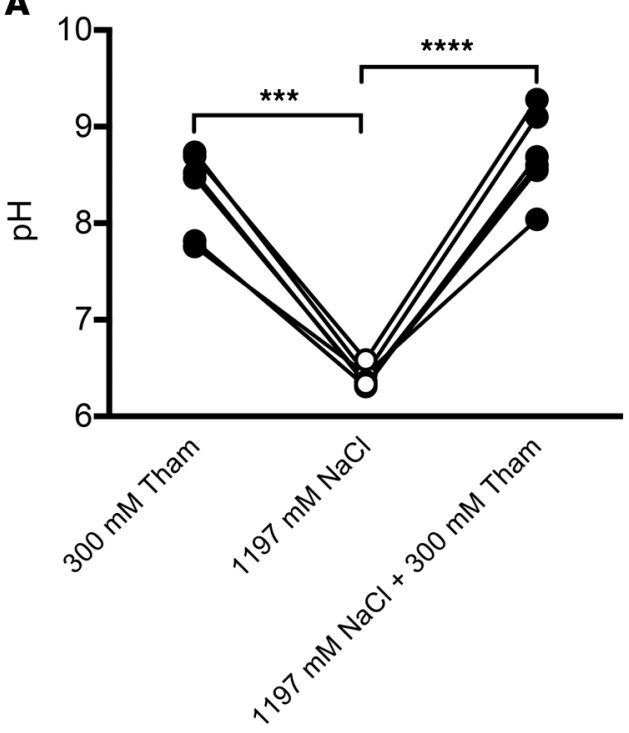

B

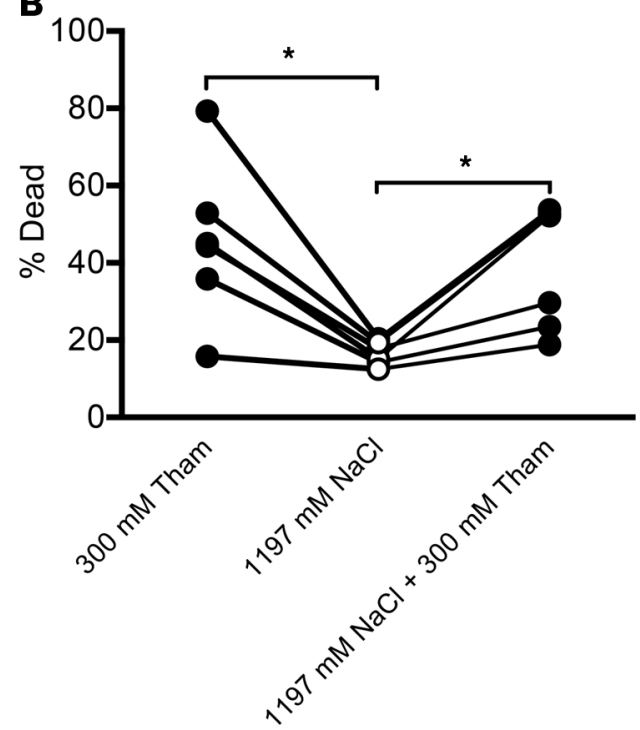

Figure 7. Antimicrobial activity of sputum from subjects with cystic fibrosis (CF). Data represent $\mathrm{pH}$ and antimicrobial activity of CF sputum mixed at 1:1 (v/v) with $300 \mathrm{mM}$ tromethamine (Tham), 1,197 mM NaCl, or a combination of 1,197 mM NaCl/300 mM Tham. (A) CF sputum pH. (B) CF sputum antimicrobial activity. Each data point indicates sputum from a different donor. $n=6$, 1-way ANOVA with Holm-Sidak's Multiple Comparison Test, ${ }^{*} P<0.05,{ }^{* * *} P<0.005,{ }^{* * * *} P<0.001$.

\section{Methods}

CF sputum preparation. We recruited adults diagnosed with CF and attending the University of Iowa Hospital and Clinics CF clinic. Patients were asked to swallow saliva and to expectorate all secretions during routine clinic visits. Sputum plugs were visually identified and separated from saliva, weighed, and stored at $-70^{\circ} \mathrm{C}$ in small, tightly sealed containers to minimize water loss. Sputum was mixed in a $1: 1 \mathrm{v} / \mathrm{v}$ with either $200 \mathrm{mM} \mathrm{NaCl}, 200 \mathrm{mM} \mathrm{NaHCO}$, 1,197 mM NaCl, $300 \mathrm{mM}$ Tham, or 1,197 mM NaCl/300 mM Tham. To guarantee adequate mixing of sputum with the different solutions, the mixture was homogenized (Sonic Dismembrator Model 100, Fisher Scientific) for 30 seconds. All experiments were conducted in a humidified chamber with constant $5 \% \mathrm{CO}_{2}$.

pH measurements. To measure nasal $\mathrm{pH}$, we used a Sandhill ZepHr PHNS-P (Sandhill Scientific) Mobidium $\mathrm{pH}$ probe with an internal reference electrode as previously described (40). Prior to each study, the $\mathrm{pH}$ probe was calibrated in buffer solutions of $\mathrm{pH} \mathrm{6,} 7$ and 8 (VWR). Vt was recorded with an Oakton $\mathrm{pH} 6+$ meter (Cole-Palmer) and corrected to temperature. The probe was positioned at $6 \mathrm{~cm}$ from the most caudal aspect of the columella. The probe remained in position until the readings were stable. All measurements were taken from the right nostril and by the same operator. Subjects on intranasal medications (steroids or anticholinergics) or with history of nasal or sinus surgery were excluded from the study. Adverse events, including nasal congestion or epistaxis, were collected but none reported.

To measure $\mathrm{pH}$ in sputum, we used a needle-type fiber optic $\mathrm{pH}$ meter (World Precision Instruments) (20). The $\mathrm{pH}$ meter was calibrated before each set of measurements using standard $\mathrm{pH}$ buffer solutions. All measurements were obtained in a humidified chamber at $37^{\circ} \mathrm{C}$ and constant $5 \% \mathrm{CO}_{2}$ to mimic physiologic conditions.

To measure $\mathrm{pH}$ in pigs in vivo, we used noninvasive dual lifetime referencing to interrogate a $3 \times 3 \mathrm{~mm}$ planar optode ( $\mathrm{pH}$ sensitive foil, PreSens $\mathrm{GmbH}$ ) applied directly to the tracheal surface of anesthetized pigs (20). $\mathrm{pH}$-dependent polarized light phase shift was measured using a single-channel $\mathrm{pH}$ meter $(\mathrm{pH}-1$ mini; PreSens $\mathrm{GmbH}$ ). The tip of the fiber optic $\mathrm{pH}$ meter was kept at the same constant distance from the tracheal surface in all samples and confirmed by recording the amplitude. Calibration before each set of measurements was done by measuring phase shift from flat filters soaked in standard $\mathrm{pH}$ buffers. All measurements were obtained in a humidified chamber at $37^{\circ} \mathrm{C}$ and constant $5 \% \mathrm{CO}_{2}$ to mimic physiologic conditions.

Nasal Vt measurements. Nasal Vt measurements were obtained in subjects with CF after Tham administration according to the description by Solomon et al. (60) with Electronic Data Capture (ADInstruments), $\mathrm{KCl}$ 
calomel electrodes (Thermo Fischer Scientific Inc.), and 3\% agar nasal catheter and reference bridges (61).

Methods for measuring buffering capacity of $\mathrm{HCO}_{3}^{-}$and Tham. An automated endpoint titration was carried out using Titralab 856 workstation (Radiometer Analytical). We measured $\mathrm{pH}$ using calomel combined $\mathrm{pH}$ electrode (pHC4000, Radiometer Analytical). $\mathrm{HCl}(100 \mathrm{mM})$ was delivered into $5 \mathrm{ml}$ of buffer at a rate of $0.2 \mathrm{ml} / \mathrm{min}$. Titration was carried out to endpoint of $\mathrm{pH} 3$. The volume of $\mathrm{HCl}$ delivered was recorded and used to calculate the acid equivalents needed to raise $\mathrm{pH}$ by 1 unit or buffering capacity.

Methods for administering $\mathrm{HCO}_{3}^{-}$or Tham. To alter tracheal $\mathrm{pH}$ in pigs using $\mathrm{HCO}_{3}^{-}$or Tham, we aerosolized the solutions to the exposed tracheal surface as previously described (20). Pigs were initially sedated with Ketamine (Ketaject, Phoenix; $20 \mathrm{mg} / \mathrm{kg}$, i.m. injection) and Xylazine (AnaSed, Lloyd; $2 \mathrm{mg} / \mathrm{kg}$, i.m. injection) and anesthetized using Propofol (Diprivan, Fresenius Kabi; 2 mg/kg, i.v. injection). The trachea was surgically exposed and accessed anteriorly. A small anterior window through the tracheal rings accessed a tracheal window to interventions and $\mathrm{pH}$ measurements. All studies were obtained in a 100\% humidified chamber at $37^{\circ} \mathrm{C}$ and constant $5 \% \mathrm{CO}_{2}$ to mimic physiologic conditions.

To change nasal $\mathrm{pH}$ in human nostrils, we administered Tham intranasally using a $250 \mu 1$ preloaded Accuspray syringe (BD Biosciences) (40).

Bacterial killing assays. To interrogate individual bacteria killing in CF sputum or in pigs, we used bacteria-coated grid assays $(20,24)$. Gold grids (200 mesh, Ted Pella) were functionalized using a series of intervention: $100 \mathrm{mM}$ 11-mercaptoundecanoic acid (MUA in 100\% alcohol, Sigma-Aldrich) for 60 minutes at room temperature; 1:1 mixture of $100 \mathrm{mM}$ N-ethyl-N-(3-diethylaminopropyl) carbodiimide (EDC); 100 $\mathrm{mM}$ N-hydroxysuccinimide (NHS) for 30 minutes at room temperature; and $0.1 \mathrm{mg} / \mathrm{ml}$ Neutravidin (Sigma-Aldrich) at $37^{\circ} \mathrm{C}$ for 1 hour.

We used 2 different strains of $S$. aureus (SH1000, a human strain for CF sputum killing studies, and SA43, a porcine strain for pig studies). Bacteria were grown to mid-log phase, incubated with $0.2 \mathrm{mg} / \mathrm{ml} \mathrm{N}$-hydroxysulphosuccinimide-biotin (sulpho-NHS-biotin) for 60 minutes at room temperature, quenched with $100 \mathrm{mM}$ glycine to bind excess free biotin, and allowed to attach to Neutravidin-coated grids for 15 minutes prior to the experiment.

After bacteria-coated grids were exposed to pig trachea for 5 minutes or CF sputum for 15 minutes, they were immediately rinsed in phosphate buffered saline and stained with SYTO9/propidium iodide (Live/Dead BacLight Bacterial viability assay, Invitrogen), mounted on slides, and imaged on a laser-scanning confocal microscope (Olympus FV1000). Live (green) and dead (red) bacteria were automatically counted using Image-based Tool for Counting Nuclei (ITCN 1.6, UCSB Center for Bio-Image Informatics) an ImageJ (NIH) plugin.

Antimicrobial factors and luminescence antibacterial assay. ASL antimicrobial factors included recombinant human $\beta$-defensin-3 hBD-3 (Peprotech) and human LL-37 (AnaSpec). Cationic peptides were dissolved in acidified water $(0.01 \%$ acetic acid) that contained $0.1 \%$ BSA.

We used $S$. aureus Xen-29 (Caliper LifeSciences Bioware). S. aureus Xen-29 was derived from S. aureus 12600, a pleural fluid isolate, which is also designated as NCTC8532. S. aureus Xen-29 possesses a stable copy of the modified Photorhabdus luminescens luxABCDE operon at a single integration site on the bacterial chromosome. For maintenance of luminescence, the bacteria were grown in Tryptic Soy Broth (TSB) in the presence of kanamycin $(10 \mu \mathrm{g} / \mathrm{ml})$.

Antimicrobial peptide activity was tested in a buffer composed of $1 \%$ TSB (casein peptone $17 \mathrm{~g} / 1$, soya peptone $3 \mathrm{~g} / 1, \mathrm{NaCl} 5 \mathrm{~g} / 1, \mathrm{~K}_{2} \mathrm{HPO}_{4} 2.5 \mathrm{~g} / 1$, glucose $2.5 \mathrm{~g} / 1$ ) and supplemented with $10 \mathrm{mM}$ potassium phosphate buffer with $\mathrm{pH}$ adjusted by varying the ratio of monobasic to dibasic phosphate and $100 \mathrm{mM}$ $\mathrm{NaCl}$ to achieve an ionic strength of $125 \mathrm{mM}$.

Bacteria were grown overnight at $37^{\circ} \mathrm{C}$ in medium described above, diluted $1: 100$, and grown to exponential phase. Bacteria were harvested by centrifugation and suspended in the $1 \%$ TSB buffer. Bacteria (5 $\times 10^{4} \mathrm{CFU}$ ) were incubated with antimicrobial factors in 96-well plates (Optiplate; Packard Instruments) in a total volume of $120 \mu \mathrm{l}$. Luminescence was measured with a luminometer (Spectra Max L, Molecular Devices) and reported as relative light units (RLU). A previous study determined that reductions in luminescence have an excellent correlation with a decrease in CFU (59). All experiments included control bacteria that did not receive antimicrobials but were incubated in buffer of identical ionic strength and $\mathrm{pH}$. Data are shown as relative luminescence as a percentage of control (RLU \% control).

Preparation of isohydric (same $\mathrm{pH}$ ) solutions. To test antimicrobial peptide activity under the same $\mathrm{pH}$ conditions and increasing concentrations of $\mathrm{HCO}_{3}^{-}$, we used 4 solutions all adjusted to the same $\mathrm{pH}$ of 7.5 
and the same ionic strength ( $161 \mathrm{mM}$ in the presence of $\mathrm{CaCl}_{2}$ or $\mathrm{MgSO}_{4}$ and $\sim 154 \mathrm{mM}$ in the absence of $\mathrm{CaCl}_{2}$ or $\mathrm{MgSO}_{4}$ ) and supplemented with $1 \% \mathrm{TSB}$. To test the effect of increasing $\mathrm{HCO}_{3}{ }^{-}$concentrations at the same $\mathrm{pH}$ in the absence of calcium or magnesium, we used the same 4 solutions without the addition of $\mathrm{CaCl}_{2}$ or $\mathrm{MgSO}_{4}$ :

$10 \mathrm{mM} \mathrm{NaHCO}$ : $\mathrm{NaCl} 140 \mathrm{mM}, \mathrm{KCl} 3 \mathrm{mM}, \mathrm{CaCl}_{2} 1 \mathrm{mM}, \mathbf{N a H C O}_{3} 10$ mM, NaH $\mathrm{PO}_{4} 1.25 \mathrm{mM}$, $\mathrm{MgSO}_{4} 1 \mathrm{mM}$, D-glucose $10 \mathrm{mM}, \mathbf{C O}_{2} 2 \%$.

$26 \mathrm{mM} \mathrm{NaHCO}$ : NaCl $124 \mathrm{mM}, \mathrm{KCl} 3 \mathrm{mM}, \mathrm{CaCl}_{2} 1 \mathrm{mM}, \mathbf{N a H C O}_{3} 26$ mM, NaH $\mathrm{PO}_{4} 1.25 \mathrm{mM}$, $\mathrm{MgSO}_{4} 1 \mathrm{mM}$, D-glucose $10 \mathrm{mM}, \mathbf{C O}_{\mathbf{2}} \mathbf{5 \%}$.

$50 \mathrm{mM} \mathrm{NaHCO}$ : $\mathrm{NaCl} 100 \mathrm{mM}, \mathrm{KCl} 3 \mathrm{mM}, \mathrm{CaCl}_{2} 1 \mathrm{mM}, \mathbf{N a H C O}_{3} \mathbf{5 0} \mathbf{~ m M}, \mathrm{NaH}_{2} \mathrm{PO}_{4} 1.25 \mathrm{mM}$, $\mathrm{MgSO}_{4} 1 \mathrm{mM}$, D-glucose $10 \mathrm{mM}, \mathbf{C O}_{2} \mathbf{9 \%}$.

$80 \mathrm{mM} \mathrm{NaHCO}$ : $\mathrm{NaCl} 70 \mathrm{mM}, \mathrm{KCl} 3 \mathrm{mM}, \mathrm{CaCl}_{2} 1 \mathrm{mM}, \mathbf{N a H C O}_{3} 80$ mM, NaH $\mathrm{PO}_{4} 1.25 \mathrm{mM}$, $\mathrm{MgSO}_{4} 1 \mathrm{mM}$, D-glucose $10 \mathrm{mM}, \mathbf{C O}_{2} \mathbf{1 2} \%$.

Animals. We studied both female and male newborn pigs with targeted disruption of the CFTR gene $C F T R^{-/-}$, generated from mating $C F T R^{+/-}$pigs. We also studied the WT littermates. We obtained all pigs from Exemplar Genetics.

Statistics. Data are presented as points from individual humans or animals or sputum samples obtained from individual donors, with mean \pm SEM indicated by bars. For statistical analysis, we used a Wilcoxon signed-rank test or a Wilcoxon Mann Whitney test to compare 2 groups and a 1-way ANOVA for multiple comparisons. In Figure 7, A and B, and Figure 6C, we used Holm-Sidak's Multiple Comparison Test for pairwise differences in $\mathrm{pH}$ or bacterial killing. Differences were considered statistically significant at $P<0.05$.

Study approval. The University of Iowa Animal Care and Use Committee approved all animal studies. The University of Iowa IRB approved all human studies and collection of sputum samples. A written informed consent was received from participants prior to inclusion in the study.

\section{Author contributions}

MHAA, MJW, DAS, and JZ designed studies. MHAA, JLL, NDG, KAS, JAR, and PJT conducted experiments and acquired data. MHAA, DAS, MJW, and JZ analyzed data. MHAA, DAS, PST, MJW, and JZ wrote the manuscript.

\section{Acknowledgments}

The authors thank Michael Shasby for valuable discussions, Viral Shah for technical assistance, and Jamie Schwartz for her help with the manuscript preparation. This work was funded by the NIH (to M.J. Welsh, D.A. Stoltz, and J. Zabner) Pathogenesis PPG HL091842, and by the Roy J Carver Charitable Trust. M.H. Abou Alaiwa was funded by a Cystic Fibrosis Foundation research development program. M.J. Welsh is an investigator of the Howard Hughes Medical Institute.

Address correspondence to: Joseph Zabner, University of Iowa Carver College of Medicine, Internal Medicine, Pulmonary C33G GH, Iowa City, Iowa 52242, USA. Phone: 319.356.4419; E-mail: joseph-zabner@uiowa.edu.

1. Gallo RL, Hooper LV. Epithelial antimicrobial defence of the skin and intestine. Nat Rev Immunol. 2012;12(7):503-516.

2. Zasloff M. Antimicrobial peptides of multicellular organisms. Nature. 2002;415(6870):389-395

3. Hancock RE, Scott MG. The role of antimicrobial peptides in animal defenses. Proc Natl Acad Sci U S A. 2000;97(16):88568861 .

4. Boman HG. Peptide antibiotics and their role in innate immunity. Annu Rev Immunol. 1995;13:61-92.

5. Waterer GW. Airway defense mechanisms. Clin Chest Med. 2012;33(2):199-209.

6. Wine JJ, Joo NS. Submucosal glands and airway defense. Proc Am Thorac Soc. 2004;1(1):47-53.

7. Knowles MR, Boucher RC. Mucus clearance as a primary innate defense mechanism for mammalian airways. J Clin Invest. 2002;109(5):571-577.

8. Robinson M, Bye PT. Mucociliary clearance in cystic fibrosis. Pediatr Pulmonol. 2002;33(4):293-306.

9. Wanner A, Salathe M, O'Riordan TG. Mucociliary clearance in the airways. Am J Respir Crit Care Med. 1996;154(6 pt 1):18681902.

10. Stoltz DA, Meyerholz DK, Welsh MJ. Origins of cystic fibrosis lung disease. N Engl J Med. 2015;372(16):1574-1575.

11. Marthinsen L, Kornfält R, Aili M, Andersson D, Westgren U, Schaedel C. Recurrent Pseudomonas bronchopneumonia and other symptoms as in cystic fibrosis in a child with type I pseudohypoaldosteronism. Acta Paediatr. 1998;87(4):472-474.

12. Mall M, Grubb BR, Harkema JR, O’Neal WK, Boucher RC. Increased airway epithelial $\mathrm{Na}^{+}$absorption produces cystic fibrosis-like lung disease in mice. Nat Med. 2004;10(5):487-493. 
13. Fischer H, Widdicombe JH, Illek B. Acid secretion and proton conductance in human airway epithelium. Am JPhysiol Cell Physiol. 2002;282(4):C736-C743.

14. Widdicombe JH. Regulation of the depth and composition of airway surface liquid. J Anat. 2002;201(4):313-318

15. Guggino WB. Cystic fibrosis and the salt controversy. Cell. 1999;96(5):607-610.

16. Wine JJ. Acid in the airways. Focus on "Hyperacidity of secreted fluid from submucosal glands in early cystic fibrosis". Am J Physiol Cell Physiol. 2006;290(3):C669-C671.

17. Zabner J, Smith JJ, Karp PH, Widdicombe JH, Welsh MJ. Loss of CFTR chloride channels alters salt absorption by cystic fibrosis airway epithelia in vitro. Mol Cell. 1998;2(3):397-403.

18. Matsui $\mathrm{H}$, et al. Evidence for periciliary liquid layer depletion, not abnormal ion composition, in the pathogenesis of cystic fibrosis airways disease. Cell. 1998;95(7):1005-1015.

19. Smith JJ, Travis SM, Greenberg EP, Welsh MJ. Cystic fibrosis airway epithelia fail to kill bacteria because of abnormal airway surface fluid. Cell. 1996;85(2):229-236.

20. Pezzulo AA, et al. Reduced airway surface $\mathrm{pH}$ impairs bacterial killing in the porcine cystic fibrosis lung. Nature. 2012;487(7405):109-113.

21. Hoegger MJ, et al. Cystic fibrosis. Impaired mucus detachment disrupts mucociliary transport in a piglet model of cystic fibrosis. Science. 2014;345(6198): 25124441.

22. Gibson RL, Burns JL, Ramsey BW. Pathophysiology and management of pulmonary infections in cystic fibrosis. Am J Respir Crit Care Med. 2003;168(8):918-951.

23. Cystic Fibrosis Foundation. Cystic Fibrosis Foundation, Patient Registry: Annual Data Report 2008. Bethesda, Maryland, USA; 2008

24. Abou Alaiwa $\mathrm{MH}$, et al. $\mathrm{pH}$ modulates the activity and synergism of the airway surface liquid antimicrobials $\beta$-defensin-3 and LL-37. Proc Natl Acad Sci U S A. 2014;111(52):18703-18708.

25. Tang XX, et al. Acidic pH increases airway surface liquid viscosity in cystic fibrosis. J Clin Invest. 2016;126(3):879-891.

26. Luchsinger PC. The use of 2-amino-2-hydroxymethyl-1,3-propanediol in the management of respiratory acidosis. Ann $N Y$ Acad Sci. 1961;92:743-750.

27. Nahas GG, et al. Guidelines for the treatment of acidaemia with THAM. Drugs. 1998;55(2):191-224.

28. Brasch H, Thies E, Iven H. Pharmacokinetics of TRIS (hydroxymethyl-)aminomethane in healthy subjects and in patients with metabolic acidosis. Eur J Clin Pharmacol. 1982;22(3):257-264.

29. Ventavis (iloprost) inhalation solution. [Prescribing information]. South San Francisco, California, USA: Actelion Pharmaceuticals US, Inc.; 2009.

30. Quadir M, Zia H, Needham TE. Development and evaluation of nasal formulations of ketorolac. Drug Deliv. 2000;7(4):223229.

31. Armstrong DS, et al. Lower airway inflammation in infants and young children with cystic fibrosis. Am J Respir Crit Care Med. 1997;156(4 pt 1):1197-1204

32. Wong JK, Ranganathan SC, Hart E, Australian Respiratory Early Surveillance Team for Cystic Fibrosis (AREST CF). Staphylococcus aureus in early cystic fibrosis lung disease. Pediatr Pulmonol. 2013;48(12):1151-1159.

33. Aslan S, Kandi冈 H, Akgun M, Cakir Z, Inandi T, Görgüner M. The effect of nebulized NaHCO3 treatment on "RADS" due to chlorine gas inhalation. Inhal Toxicol. 2006;18(11):895-900.

34. Bosse GM. Nebulized sodium bicarbonate in the treatment of chlorine gas inhalation. J Toxicol Clin Toxicol. 1994;32(3):233-241.

35. Vinsel PJ. Treatment of acute chlorine gas inhalation with nebulized sodium bicarbonate. J Emerg Med. 1990;8(3):327-329

36. Maisetta G, et al. Evaluation of the inhibitory effects of human serum components on bactericidal activity of human beta defensin 3. Peptides. 2008;29(1):1-6.

37. Turner J, Cho Y, Dinh NN, Waring AJ, Lehrer RI. Activities of LL-37, a cathelin-associated antimicrobial peptide of human neutrophils. Antimicrob Agents Chemother. 1998;42(9):2206-2214.

38. McShane D, Davies JC, Davies MG, Bush A, Geddes DM, Alton EW. Airway surface pH in subjects with cystic fibrosis. Eur Respir J. 2003;21(1):37-42.

39. Garland AL, et al. Molecular basis for pH-dependent mucosal dehydration in cystic fibrosis airways. Proc Natl Acad Sci U S A. 2013;110(40):15973-15978.

40. Abou Alaiwa MH, et al. Neonates with cystic fibrosis have a reduced nasal liquid pH; a small pilot study. J Cyst Fibros. 2014;13(4):373-377.

41. Kadurugamuwa JL, et al. Direct continuous method for monitoring biofilm infection in a mouse model. Infect Immun. 2003;71(2):882-890.

42. Greene CM, McElvaney NG. Proteases and antiproteases in chronic neutrophilic lung disease - relevance to drug discovery. $B r J$ Pharmacol. 2009;158(4):1048-1058.

43. Moncla BJ, Pryke K, Rohan LC, Graebing PW. Degradation of naturally occurring and engineered antimicrobial peptides by proteases. Adv Biosci Biotechnol. 2011;2(6):404-408.

44. Sawa T, et al. Intraluminal water increases expression of plasmid DNA in rat lung. Hum Gene Ther. 1996;7(8):933-941.

45. Wang G, et al. Increasing epithelial junction permeability enhances gene transfer to airway epithelia In vivo. Am J Respir Cell Mol Biol. 2000;22(2):129-138.

46. Donaldson SH, Bennett WD, Zeman KL, Knowles MR, Tarran R, Boucher RC. Mucus clearance and lung function in cystic fibrosis with hypertonic saline. N Engl J Med. 2006;354(3):241-250.

47. Elkins MR, et al. A controlled trial of long-term inhaled hypertonic saline in patients with cystic fibrosis. $N$ Engl JMed. 2006;354(3):229-240.

48. Lee IH, Cho Y, Lehrer RI. Effects of $\mathrm{pH}$ and salinity on the antimicrobial properties of clavanins. Infect Immun. 1997;65(7):2898-2903.

49. Goldman MJ, Anderson GM, Stolzenberg ED, Kari UP, Zasloff M, Wilson JM. Human beta-defensin-1 is a salt-sensitive antibiotic in lung that is inactivated in cystic fibrosis. Cell. 1997;88(4):553-560.

50. Wu M, Maier E, Benz R, Hancock RE. Mechanism of interaction of different classes of cationic antimicrobial peptides with planar bilayers and with the cytoplasmic membrane of Escherichia coli. Biochemistry. 1999;38(22):7235-7242. 
51. Park IY, Cho JH, Kim KS, Kim YB, Kim MS, Kim SC. Helix stability confers salt resistance upon helical antimicrobial peptides. J Biol Chem. 2004;279(14):13896-13901.

52. Singh PK, Tack BF, McCray PB Jr, Welsh MJ. Synergistic and additive killing by antimicrobial factors found in human airway surface liquid. Am J Physiol Lung Cell Mol Physiol. 2000;279(5):L799-L805.

53. USFDA. Drugs@FDA. US Department of Health and Human Services Web site. http://www.accessdata.fda.gov/scripts/cder/ drugsatfda/index.cfm?fuseaction=Search.Label_ApprovalHistory-apphist. Accessed May 10, 2016

54. Elkins MR, Bye PT. Inhaled hypertonic saline as a therapy for cystic fibrosis. Curr Opin Pulm Med. 2006;12(6):445-452 .

55. Gould NS, Gauthier S, Kariya CT, Min E, Huang J, Brian DJ. Hypertonic saline increases lung epithelial lining fluid glutathione and thiocyanate: two protective CFTR-dependent thiols against oxidative injury. Respir Res. 2010;11:119.

56. Bergsson G, et al. LL-37 complexation with glycosaminoglycans in cystic fibrosis lungs inhibits antimicrobial activity, which can be restored by hypertonic saline. J Immunol. 2009;183(1):543-551.

57. Reeves EP, Williamson M, O’Neill SJ, Greally P, McElvaney NG. Nebulized hypertonic saline decreases IL-8 in sputum of patients with cystic fibrosis. Am J Respir Crit Care Med. 2011;183(11):1517-1523.

58. Williams HD, Behrends V, Bundy JG, Ryall B, Zlosnik JE. Hypertonic saline therapy in cystic fibrosis: Do population shifts caused by the osmotic sensitivity of infecting bacteria explain the effectiveness of this treatment? Front Microbiol. 2010;1:120

59. Travis SM, et al. Activity of abundant antimicrobials of the human airway. Am J Respir Cell Mol Biol. 1999;20(5):872-879.

60. Solomon GM, et al. An international randomized multicenter comparison of nasal potential difference techniques. Chest. 2010;138(4):919-928.

61. Rowe SM, Clancy JP, Wilschanski M. Nasal potential difference measurements to assess CFTR ion channel activity. Methods Mol Biol. 2011;741:69-86. 